\title{
MODEL PEMBELAJARAN PENEMUAN TERBIMBING BERBANTUAN PROGRAM KOMPUTER-EXEL UNTUK MENINGKATKAN HASIL BELAJAR SISWA POKOK BAHASAN TURUNAN FUNGSI KELAS XI IPA SMA AL-ULUM MEDAN
}

\author{
Agusman $^{1}$ \\ ${ }^{1}$ Jurusan Pendidikan Matematika Universitas Muslim Nusantara Al-Washliyah Medan \\ Email: '1gunawan_guru@yahoo.co.id
}

\begin{abstract}
Abstrak
Penelitian ini dilatarbelakangi oleh rendahnya hasil belajar matematika siswa pada pokok bahasan turunan fungsi tentang menggambar grafik fungsi, berdasarkan hasil ulangan harian menunjukkan bahwa hanya 4 orang dari 32 orang siswa yang berhasil menggambar grafik fungsi dengan benar atau hanya $12,5 \%$ siswa yang mencapai ketuntasan minimal pembelajaran. Hasil refleksi pembelajaran yang dilakukan guru mengidentifikasikan bahwa masalah rendahnya hasil belajar siswa disebabkan oleh kurangnya pemahaman siswa terhadap konsep materi, kurangnya pemanfaatan media, pembelajaran hanya terpusat kepada siswa dan metode yang digunakan guru terlalu monoton. Tujuan penelitian tindakan ini adalah untuk meningkatkan keefektifan belajar sisiwa siswa dan meningkatkan hasil belajar siswa dalam belajar matematika pada pokok bahasan turunan fungsi tentang menggambar grafik fungsi melalui model pembelajaran penemuan terbimbing berbantuan komputer-excel di kelas XI IPA SMA Al-Ulum Medan. Subjek penelitian tindakan ini adalah siswa kelas XI IPA SMA Al-Ulum Medan yang berjumlah 32 orang yang terdiri dari 8 orang laki-laki dan 24 orang perempuan. Penelitian tindakan ini dilaksanakan dalam dua siklus. Kegiatan pada setiap siklus meliputi: perencanaan, pelaksanaan, pengamatan, dan refleksi. Instrumen yang digunakan dalam penelitian tindakan ini adalah tes tertulis bentuk essay. Hasil belajar matematika siswa ditunjukan dengan presentase ketuntasan kelas pada siklus I mencapai 56,25\% dan pada siklus II mencapai $71,88 \%$. Dari data tersebut, dapat disimpulkan bahwa hasil belajar matematika siswa pada pada pokok bahasan turunan fungsi melalui model pembelajaran penemuan terbimbing berbantuan komputer-excel di kelas XI IPA SMA Al-Ulum Medan meningkat.
\end{abstract}

Kata Kunci : Hasil belajar, turunan fungsi, model pembelajaran, model penemuan terbimbing, komputer program excel

\section{PENDAHULUAN}

Kubus merupakan bagian dari geometri. Kubus dipelajari oleh siswa mulai dari sekolah dasar hingga jenjang perguruan tinggi. Kubus merupakan ruang dimana siswa berada, hidup dan bergerak. Bangun ruang sisi datar sangat dekat dengan kehidupan siswa. 


\section{Agusman}

Oleh karena itu, siswa harus belajar mengetahui (to know), dan menelaah (to explore) geometri termasuk kubus (Freudenthal dalam Afgani, 2011).

Walled dan John (2008) menyatakan bahwa pemahaman merupakan kemampuan penting dalam mempelajari geometri. Sudjana (2011) menjelaskan bahwa pemahaman merupakan tingkat hasil belajar yang lebih tinggi daripada pengetahuan yang diperoleh, perlu adanya mengenal atau mengetahui untuk dapat memahami. Kemampuan pemahaman yang diperlukan siswa dalam mempelajari geometri adalah pemahaman konsep.

Donovan, Bransford, \& Pellegrion dalam Jbeili (2012) menyatakan bahwa pemahaman konsep menunjuk kepada kemampuan siswa untuk menghubungkan gagasan baru dalam matematika dengan gagasan yang siswa ketahui, untuk menggambarkan situasi matematika dalam cara-cara yang berbeda dan untuk menentukan perbedaan antara penggambaran ini. Pernyataan ahli tersebut menyimpulkan bahwa kemampuan pemahaman konsep yang baik diperlukan dalam pembelajaran geometri dalam memahami definisi kubus. Oleh karena itu, guru sebelum memberikan konsep baku tentang bangun ruang kubus, guru perlu mengetahui konsep atau gagasan awal siswa terhadap bangun ruang kubus.

Konsep merupakan sebuah abstraksi dari ciri-ciri yang mempermudah komunikasi manusia dan memungkinkan manusia untuk berpikir. Pemahaman suatu konsep tertentu yang dipahami oleh siswa disebut sebagai konsepsi (Tayubi, 2005). Setiap siswa telah memiliki konsep awal sendiri-sendiri dan berbeda-beda sebelum mempelajari konsep yang benar di sekolah melalui asimiliasi konsep (Rustaman, 2005).

Konsep kubus dalam matematika telah disepakati oleh para matematikawan, akan tetapi dalam perjalanan pembelajaran matematika masih saja terdapat siswa yang memiiki pemahaman konsep kubus yang berbeda-beda. Oleh karena itu, penelitian ini bertujuan untuk mendeskripsikan konsepsi awal siswa tentang definsi kubus. Hasil dari suatu proses pembelajaran adalah terbentuknya manusia yang cerdas, terampil, dan berakhlak mulia. Hal ini sejalan dengan tujuan pendidikan nasional yaitu mengembangkan kemampuan dan membentuk watak serta peradaban bangsa yang bermartabat dalam rangka mencerdaskan kehidupan bangsa, bertujuan untuk berkembangnya potensi peserta didik agar menjadi manusia yang beriman dan bertakwa kepada Tuhan Yang Maha Esa, berakhlak mulia, sehat, berilmu, cakap, kreatif, mandiri, dan menjadi warga negara yang demokratis serta bertanggung jawab (Undang-Undang Nomor 20 tahun 2003 pasal 3). Usaha-usaha perbaikan yang telah dilakukan baik pemerintah maupun guru belum banyak menampakkan kemajuan yang berarti. Sekalipun diketahui bahwa nilai ujian nasional siswa setiap tahunnya relatif tinggi, akan tetapi fakta di lapangan memberikan isyarat yang nyata bahwa hasil belajar siswa pada ulangan harian, ulangan tengah semester, ulangan akhir semester, dan ujian sekolah menunjukkan hasil yang memprihatinkan. Kondisi ini secara real dialami oleh penulis selama beberapa tahun mengampu mata pelajaran matematika, pada materi pokok aplikasi turunan yaitu menggambarkan grafik fungsi.

Hasil ulangan harian siswa menunjukkan hanya 4 orang dari 32 orang siswa yang berhasil menggambar grafik fungsi dengan benar. Setelah dilakukan remedi berkali-kali, barulah beberapa orang siswa menunjukkan hasil belajar yang meningkat. Itu pun karena tingkat kesukaran soalnya diturunkan dan pengawasan lebih dilonggarkan. Anehnya lagi, jika soal tersebut kembali muncul dalam ulangan tengah semester atau ulangan akhir semester, hasilnya akan kembali ke titik terendah yaitu jawaban siswa kebanyakan tidak benar. Fakta 
ini paling tidak telah menggambarkan bahwa mutu pendidikan di Indonesia masih rendah. Kondisi ini sejalan dengan laporan yang dirilis oleh Human Development Index (Indeks Pembangunan Manusia) pada tahun 2010 yang menempatkan Indonesia berada pada posisi 111 dari 180 negara di dunia dan urutan ke-6 dari 10 negara ASEAN. Jatuhnya IPM atau rendahnya sumber daya manusia (SDM) disebabkan masalah pendidikan, kesehatan dan kemiskinan," kata Deputi Bidang Keluarga Sejahtera dan Pemberdayaan Keluarga, Kantor Badan Koordinasi Keluarga Berencana Nasional (BKKBN) Pusat, Hardiyanto (metrotvnews, 2010).

Guru yang profesional bukanlah guru yang mudah menyerah terhadap kondisi yang kurang menguntungkan. Akan tetapi keadaan yang kurang menguntungkan ini akan dijadikan sebagai dasar untuk melakukan kebijakan-kebijakan sekalipun skalanya relatif kecil untuk merubah keadaan menjadi lebih baik. Salah satu upaya yang dapat dilakukan adalah melaksanakan pembelajaran yang mampu menarik minat siswa untuk mengikuti pembelajaran dengan sebaik-baiknya, tanpa merasa tertekan dan terintimidasi. Untuk itu ditawarkan suatu solusi pembelajaran dengan model pembelajaran penemuan terbimbing berbantuan komputer-excel untuk menggambar grafik fungsi. Melalui model pembelajaran penemuan terbimbing berbantuan komputer-excel, siswa dihadapkan kepada situasi dimana siswa bebas menyelidiki dan menarik kesimpulan. Terkaan, intuisi dan mencoba-coba (trial and error) hendaknya dianjurkan dan guru sebagai penunjuk jalan dan membantu siswa agar mempergunakan ide, konsep dan keterampilan yang sudah mereka pelajari untuk menemukan pengetahuan yang baru. Dalam model pembelajaran ini peran siswa cukup besar karena pembelajaran tidak lagi terpusat pada guru tetapi pada siswa. Guru memulai kegiatan belajar mengajar dengan menjelaskan kegiatan yang akan dilakukan siswa dan mengorganisir kelas untuk kegiatan seperti pemecahan masalah, investigasi atau aktivitas lainnya (Markaban, 2006: 15).

Dengan demikian diharapkan bahwa melalui penerapan model pembelajaran penemuan terbimbing, siswa akan terdorong untuk belajar lebih serius dan sungguh-sungguh untuk menguasai kompetensi yang ditetapkan. Sejalan dengan itu penulis mencoba melakukan penelitian dengan judul "Penerapan Model Pembelajaran Penemuan Terbimbing berbantuan Program Komputer - Excel Untuk Meningkatkan Hasil Belajar Siswa Kelas XI IPA SMA Al-Ulum Medan".

Penelitian ini bertujuan untuk meningkatkan keaktifan siswa dan hasil belajar siswa kelas XI IPA SMA Al-Ulum Medan dalam belajar matematika pada pokok bahasan turunan fungsi tentang menggambar grafik fungsi melalui model pembelajaran penemuan terbimbing berbantuan program komputer-excel.

Menurut Markaban (2006: 10) model pembelajaran penemuan terbimbing disebut juga sebagai metode penemuan yang dipandu oleh guru. Model pembelajaran ini pertama kali dikenalkan oleh Plato dalam suatu dialog antara Socrates dan seorang anak, maka sering disebut juga dengan metoda Socratic. Metode ini melibatkan suatu dialog/interaksi antara siswa dan guru di mana siswa mencari kesimpulan yang diinginkan melalui suatu urutan pertanyaan yang diatur oleh guru. Salah satu buku yang pertama menggunakan teknik penemuan terbimbing adalah tentang aritmetika oleh Warren Colburn yang pelajaran pertamanya berjudul: Intellectual Arithmetic upon the Inductive Method of Instruction, diterbitkan pada tahun (1821), yang isinya menekankan penggunaan suatu urutan pertanyaan 
dalam mengembangkan konsep dan prinsip matematika. Ini menirukan metode Socratic di mana Socrates dengan pertolongan pertanyaan yang ia tanyakan memungkinkan siswa untuk menjawab pertanyaan tersebut.

Menurut Ruseffendi (2006:329) model pembelajaran penemuan adalah pembelajaran yang mengatur pengajaran sedemikian rupa sehingga anak memperoleh pengetahuan yang sebelumnya belum diketahuinya, bukan melalui pemberitahuan, sebagian atau seluruhnya ditemukan sendiri. Dengan kata lain pembelajaran dengan metode penemuan merupakan salah satu cara untuk menyampaikan ide/gagasan dengan proses menemukan, dalam proses ini siswa berusaha menemukan konsep dan rumus dan semacamnya dengan bimbingan guru.

Sementara menurut Prince \& Felder (2006:132) belajar dengan penemuan merupakan pendekatan yang berbasis pemeriksaan. Para siswa diberi suatu pertanyaan untuk menjawab suatu masalah untuk dipecahkan atau pengamatan-pengamatan untuk dijelaskan, mengarahkan dirinya sendiri untuk melengkapi tugas-tugas, menarik kesimpulan-kesimpulan yang sesuai dengan temuannya, dan "menemukan" pengetahuan konseptual berdasarkan fakta yang diinginkan di dalam proses pembelajaran.

Model pembelajaran penemuan terbimbing merupakan model pembelajaran yang bersifat student oriented dengan teknik trial and error, menerka, menggunakan intuisi, menyelidiki, menarik kesimpulan, serta memungkinkan guru melakukan bimbingan dan penunjuk jalan dalam membantu siswa untuk mempergunakan ide, konsep, dan keterampilan yang mereka miliki untuk menemukan pengetahuan yang baru (Purnomo, 2010: 4). Lebih lanjut, Gulo (2002) mengatakan bahwa belajar dengan penemuan terbimbing merupakan usaha menemukan konsep atau prosedur atau prinsip di bawah bimbingan guru. Sejalan dengan itu, Ali (2008: 87) mengatakan bahwa model penemuan terbimbing adalah model pembelajaran penemuan yang dalam pelaksanaanya dilakukan oleh siswa berdasarkan petunjuk-petunjuk guru. Petunjuk diberikan pada umumnya berbentuk pertanyaan membimbing.

Agar pelaksanaan model penemuan terbimbing ini berjalan dengan efektif, Markaban (2006: 16) menegaskan beberapa langkah yang perlu ditempuh oleh guru adalah sebagai berikut: (a) Merumuskan masalah yang akan diberikan kepada siswa dengan data secukupnya, perumusannya harus jelas, hindari pernyataan yang menimbulkan salah tafsir sehingga arah yang ditempuh siswa tidak salah. (b) Dari data yang diberikan guru, siswa menyusun, memproses, mengorganisir, dan menganalisis data tersebut. Dalam hal ini, bimbingan guru dapat diberikan sejauh yang diperlukan saja. Bimbingan ini sebaiknya mengarahkan siswa untuk melangkah ke arah yang hendak dituju, melalui pertanyaanpertanyaan, atau LKS. (c) Siswa menyusun konjektur (prakiraan) dari hasil analisis yang dilakukannya. (d) Bila dipandang perlu, konjektur yang telah dibuat siswa tersebut diperiksa oleh guru. Hal ini penting dilakukan untuk meyakinkan kebenaran prakiraan siswa, sehingga akan menuju arah yang hendak dicapai. (e) Apabila telah diperoleh kepastian tentang kebenaran konjektur tersebut, maka verbalisasi konjektur sebaiknya diserahkan juga kepada siswa untuk menyusunnya. Di samping itu perlu diingat pula bahwa induksi tidak menjamin $100 \%$ kebenaran konjektur. (f) Sesudah siswa menemukan apa yang dicari, hendaknya guru menyediakan soal latihan atau soal tambahan untuk memeriksa apakah hasil penemuan itu benar.

Memperhatikan model penemuan terbimbing tersebut di atas dapat disampaikan kelebihan dan kekurangan yang dimilikinya. Kelebihan dari model penemuan terbimbing 
adalah sebagai berikut: (a) Siswa dapat berpartisipasi aktif dalam pembelajaran yang disajikan. (b) Menumbuhkan sekaligus menanamkan sikap inquiry (mencari-temukan). (c) Mendukung kemampuan problem solving siswa. (d) Memberikan wahana interaksi antar siswa, maupun siswa dengan guru, dengan demikian siswa juga terlatih untuk menggunakan bahasa Indonesia yang baik dan benar. (e) Materi yang dipelajari dapat mencapai tingkat kemampuan yang tinggi dan lebih lama membekas karena siswa dilibatkan dalam proses menemukannya (Marzano, 1992).

Sementara itu kekurangannya adalah sebagai berikut: (a) Untuk materi tertentu, waktu yang tersita lebih lama. (b) Tidak semua siswa dapat mengikuti pelajaran dengan cara ini. Di lapangan, beberapa siswa masih terbiasa dan mudah mengerti dengan model ceramah. (c) Tidak semua topik cocok disampaikan dengan model ini. Umumnya topik-topik yang berhubungan dengan prinsip dapat dikembangkan dengan model penemuan terbimbing.

Beberapa teori belajar yang mendasari penerapan model pembelajaran penemuan terbimbing adalah teori belajar konstruktivisme yang mengatakan bahwa siswa harus menemukan sendiri dan mentransformasikan informasi kompleks, mengecek informasi baru dengan aturan-aturan lama dan merevisinya apabila aturan-aturan itu tidak sesuai lagi. Bagi siswa agar benar-benar memahami dan dapat menerapkan pengetahuan, mereka harus bekerja memecahkan masalah, menemukan sesuatu untuk dirinya, berusaha dengan susah payah dengan ide-ide (Slavin, 1994). Masih menurut pandangan konstruktivisme, sebagaimana dikutip Suparno (1997: 18) mengatakan bahwa belajar merupakan hasil konstruksi kognitif melalui kegiatan seseorang. Pandangan ini memberikan penekanan bahwa pengetahuan adalah bentukan diri sendiri.

Kemudian menurut Teori Vygotsky seperti yang dikatakan Slavin (1994) bahwa proses pembelajaran akan terjadi jika anak bekerja atau menangani tugas-tugas yang belum dipelajari, namun tugas-tugas tersebut masih berada dalam jangkauan kemampuan mereka yang disebut zone of proximal development. Sejalan dengan itu, pada teori belajar bermakna dari Ausubel dinyatakan bahwa belajar bermakna terjadi bila siswa mencoba menghubungkan fenomena baru ke dalam struktur pengetahuan mereka. Ini terjadi melalui belajar konsep dan perubahan konsep yang sudah ada, yang mengakibatkan pertumbuhan dan perubahan struktur konsep yang telah dimiliki siswa (Suparno, 1997).

\section{METODE}

Penelitian ini dilaksanakan di SMA Al-Ulum Medan Jl. Cemara No. 10 Medan Provinsi Sumatera Utara. Waktu penelitian mulai dari bulan Maret sampai dengan Juni 2015, tepatnya pada semester genap tahun pelajaran 2014/2015.

Pendekatan yang digunakan dalam penelitian ini adalah pendekatan Kualitatif dan Kuantitatif, yaitu upaya yang dilakukan guru dalam rangka meningkatkan hasil belajar siswa pada materi pokok Turunan Fungsi (Diferensial) mata pelajaran Matematika di Kelas XI IPA. Jenis Penelitian yang dilakukan adalah Penelitian Tindakan Kelas (Class Room Action Reseach). Penelitian ini sering juga disebut dengan PTK, yaitu suatu penelitian dalam bentuk tindakan (action) yang dilaksanakan guru dalam pembelajaran di dalam kelas. Penelitian Tindakan Kelas (PTK) yang dilakukan ini terdiri dari 2 (dua) siklus, yaitu kegiatan perputaran waktu yang merupakan rangkain kegiatan yang saling berkaitan. Setelah kegiatan 
pada siklus I berlangsung diikuti oleh kegiatan pada siklus II. dimana tindakan yang dilakukan pada siklus II merupakan refleksi (cerminan) dari kegiatan pada siklus I

Subjek penelitian ini adalah siswa kelas XI IPA SMA Al-Ulum Medan tahun pelajaran 2014/2015. Banyak siswa pada kelas tersebut adalah 32 orang yang terdiri dari 8 orang laki-laki dan 24 orang perempuan. Penelitian ini dilakukan menggunakan rancangan penelitian tindakan kelas (PTK) yang terdiri dari 2 siklus atau lebih. Setiap siklus terdiri dari 4 tahap yaitu : (1) Perencanaan, (2) Pelaksanaan Tindakan, (3) Observasi (pengamatan), dan (4) Refleksi (Kemmis dan Taggart, 1988).

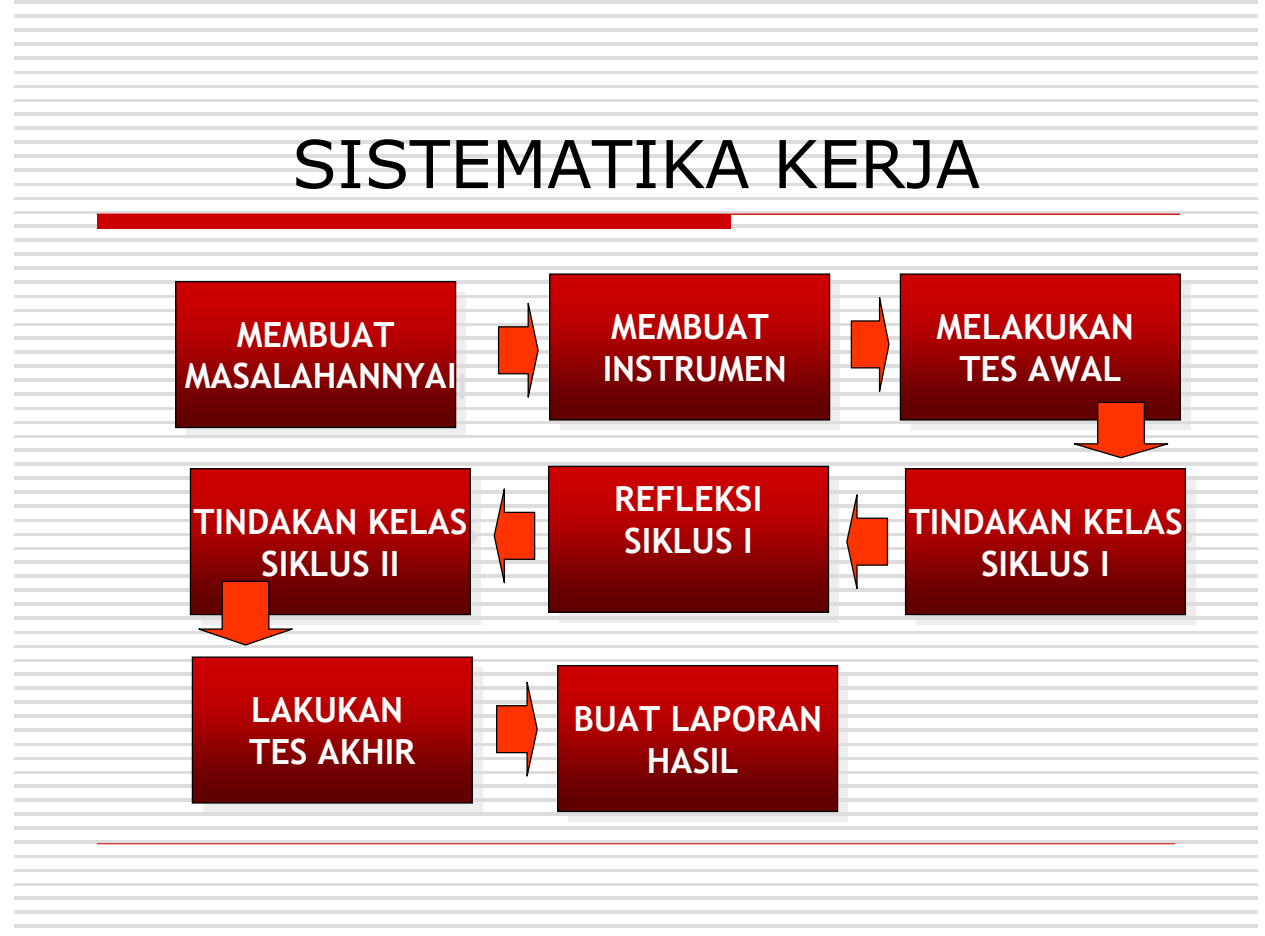

\section{Gambar 1. Prosedur Kerja Penelitian}

Alat yang digunakan dalam pengumpulan data adalah angket motivasi, tes hasil belajar dan lembar pengamatan. Teknik analisis data dalam penelitian ini dilakukan dengan teknik analisis kualitatif dan kuantitatif,. Dimana analisis kuantitatif seperti biasanya dilakukan dengan menggunakan statistik deskriftif. Hasil penilaian dari tes awal, tes akhir siklus I, tes akhir siklus II dibuat rata-ratanya, ditentukan simpangan baku (standar deviasinya), ditentukan nilai tertinggi, nilai terendah, serta rentang nilai pada setiap tes yang dilakukan. Berapa siswa yang sudah tuntas belajar (kompeten) dan berapa jumlah siswa yang belum tuntas belajar, kemudian masing-masing ditentukan presentasenya. Sementara untuk analisis kualitatif, data diperoleh dengan membuat data kategori (pengelompokan data berdasarkan mastery level) sesuai dengan sistem penilaian yang berlaku dalam Kurikulum Tingkat Satuan Pendidikan (KTSP) di SMA Swasta Al-Ulum Medan, pada mata pelajaran Matematika di kelas XI IPA adalah sebagai berikut.

Tabel 1. Kategori Tingkatan Nilai Siswa

\begin{tabular}{|cl}
\hline Interval Nilai & Tingkat Kemam \\
\hline $90-100$ & Sangat Tinggi \\
$80-89$ & Tinggi \\
$65-79$ & Sedang \\
$55-64$ & Rendah
\end{tabular}


00 - $54 \quad$ Sangat Rendah

Kriteria seorang siswa dinyatakan tuntas dalam pembelajaran jika hasil belajar yang diperoleh $>70$. Indikator keberhasilan tindakan untuk setiap siklus adalah jika jumlah siswa yang tuntas dalam pembelajaran $>65 \%$.

\section{HASIL DAN PEMBAHASAN}

Hasil yang diperoleh dari pelaksanaan siklus 1 adalah rata-rata dan simpangan baku hasil belajar siswa sebesar 69,25 dan 12,16. Banyak siswa yang tuntas adalah sebanyak 18 orang $(56,25 \%)$. Karena indikator keberhasilan yang ditetapkan belum tercapai, perlu dicari kelemahan-kelemahan tindakan yang dilakukan pada siklus 1. Selanjutnya akan dilakukan perbaikan pembelajaran pada siklus 2

Dari hasil pelaksanaan tindakan pada siklus 2, diketahui bahwa siswa yang benarbenar serius mengikuti pembelajaran adalah sebanyak 30 orang $(93,75 \%)$ dan siswa yang aktif dalam kerja kelompok adalah sebanyak 28 orang $(87,50 \%)$. Hasil ini menunjukkan bahwa tingkat partisipasi siswa mengikuti pembelajaran dengan model pembelajaran penemuan terbimbing berbantuan komputer-excel termasuk kategori tinggi. Hasil penelitian yang diperoleh pada siklus 2, khususnya pada hasil belajar siswa sudah mencapai indikator keberhasilan yang telah ditetapkan sebelumnya. Dengan demikian proses penelitian dianggap cukup dan tidak perlu dilanjutkan siklus 3.

Mencermati hasil penelitian yang diuraikan di atas, diketahui bahwa melalui model pembelajaran penemuan terbimbing berbantuan komputer-excel telah terjadi peningkatan hasil belajar siswa yakni rata-rata hasil belajar 69,25 pada siklus 1 menjadi 72,66 pada siklus 2. Demikian juga dengan presentase tingkat ketuntasan hasil belajar dari $56,25 \%$ pada siklus 1 menjadi $71,88 \%$ pada siklus 2 .

\section{KESIMPULAN DAN SARAN}

Berdasarkan hasil penelitian dalam laporan penelitian ini, diambil simpulan sebagai berikut: (1) Melalui penerapan model pembelajaran penemuan terbimbing berbantuan program komputer-excel dapat meningkatkan keaktifan siswa dalam belajar matematika pada materi pokok bahasan turunan fungsi tentang menggambar grafik fungsi siswa kelas XI IPA SMA Al-Ulum Medan. (2) Melalui penerapan model pembelajaran penemuan terbimbing berbantuan komputer-excel dapat meningkatkan hasil belajar siswa pada pokok bahasan turunan fungsi tentang menggambar grafik fungsi siswa kelas XI IPA SMA Al-Ulum Medan

Sejalan dengan simpulan di atas, disampaikan saran-saran sebagai berikut: (1) Sebaiknya guru matematika menambah wawasannya dalam melakukan pembelajaran matematika dengan memanfaatkan komputer. (2) Sebaiknya siswa memperdalam pengetahuan mereka dalam melakukan proses belajar dengan memanfaatkan komputer. (3) Sebaiknya Kepala sekolah menyusun kebijakan yang berorientasi terhadap perbaikan pembelajaran dan hasil belajar dengan memanfaatkan computer.

\section{DAFTAR RUJUKAN}

Ali, M. (2008). Guru Dalam Proses Belajar Mengajar. Bandung: Sinar Baru Algesindo.

Depdiknas. (2003). Undang-Undang Sistem Pendidikan Nasional Nomor 20 Tahun 2003. Jakarta: Depdiknas.

Gulo, W. (2002). Strategi Belajar Mengajar. Jakarta: PT Gramedia Widiasarana Indonesia. 
Markaban. (2010). Model Pembelajaran Matematika Dengan Pendekatan Model Penemuan Terbimbing. Jakarta: Depdiknas.

Marzano. R. J. (1992). A Different Kind of Classroom. Teaching With Dimensions of Learning. Alexandria VA: ASCD.

Metrotvnews. (2010). http://metrotvnews.com/metromain/news/2010 /08/02/24993 /Indeks Pembangunan Manusia-Indonesia-Urutan-111-Dunia. [2 Agustus 2010. 12.30 WIB].

Prince, M. J. \& Felder. R. M. (2006). Inductive Teaching and Learning Methods: Definitions. Comparisons. and Research Bases. Journal of Engineering Education, 95 (2), 123 138.

Ruseffendi, E. T. (2006). Pengantar kepada Membantu Guru Mengembangkan Kompetensinya Dalam Pengajaran Matematika Untuk Meningkatkan CBSA. (Edisi revisi). Bandung: Tarsito.

Slavin, R. E. (1994). Cooperative Learning: Research and Practice. Second Edition. Massachusetts: Allyn and Bacon.

Suparno. (1997). Filsafat Kosntruktivisme Dalam Pendidikan. Yogyakarta: Kanisius. 